\title{
Stereological Quantification of Extraocular Muscles in Humans
}

\author{
Cuantificación Estereológica de Músculos Extraoculares en Humanos
}

\author{
San Martín, J. ${ }^{1}$; Luna, C. ${ }^{1}$; Garretón, R. ${ }^{1}$; Araneda, S. ${ }^{1}$; Salgado, C. ${ }^{1}$; Rodríguez, A. ${ }^{2} \&$ Salgado, G. ${ }^{3}$
}

SAN MARTÍN, J.; LUNA, C.; GARRETÓN, R.; ARANEDA, S.; SALGADO, C.; RODRÍGUEZ, A. \& SALGADO, G. Stereological quantification of extraocular muscles in humans. Int. J. Morphol., 39(2):506-511, 2021.

SUMMARY: The aim of this study is to quantify muscular and connective tissue volumes of extraocular muscles (EOM) in humans with no ophthalmological disease using stereology. EOM from five cadaveric non-strabismic humans were obtained. The number of muscle fibers in 5,000 $\mu^{2}$ and volume density ( $\mathrm{Vv}$ ) of muscle and collagen were measured using stereology. Comparisons between antagonist EOM were conducted using Wilcoxon signed rank test for paired samples. A secondary analysis examining differences between pairs of EOM was also conducted. Bilateral tests were performed, and significance was set at 0.05 . The horizontal rectus muscles (medial and lateral rectus) had the highest $\mathrm{Vv}$ of muscle and the lowest $\mathrm{Vv}$ of collagen. The inferior rectus muscle tended to have a fewer number of fibers per 5,000 $\mu \mathrm{m}^{2}$ than the rest of the EOM. However, these differences did not reach statistical significance. This is the first published study describing the normal histology of human EOM using stereology. Our investigation, through the quantification of the proportion of muscle and collagen tissue, as well as the number of muscle fibers in 5,000 $\mu^{2}$, establishes normal stereological parameters for EOM of humans without ophthalmological disease.

KEY WORDS: Oculomotor muscles; Humans; Histology; Anatomy.

\section{INTRODUCTION}

The oculomotor system has the role of providing a stable image in the retina and allows searching visual targets in space, with both rapid-saccadic and slow-pursuit movements. The ocular alignment and a steady fixation are key factors in order to achieve high grade visual acuity and stereopsis. The extreme precision of the ocular movements relies not only on the complex supranuclear and nuclear neural control, but also on the complex biological organization of the extraocular muscles (EOM) (Porter et al., 1995; Spencer \& Porter, 2006).

The EOM are a group of seven skeletal muscles: medial rectus (MR), lateral rectus (LR), inferior rectus (IR), superior rectus (SR), inferior oblique (IO), superior oblique (SO) and levator palpebrae (LP). These muscles show numerous differences when compared to other skeletal muscles, such as masticatory or limbs muscles. For this reason, they are actually defined as a different allotype (Hoh et al., 1989). In contrast to limbs muscles, EOM are divided in two main compartments, an orbital, more external compartment which inserts in the orbital pulleys, approximately at globe equator, and a global, more internal compartment that reaches the sclera (Büttner-Ennever, 2007). In relation to motor units (MU), the EOM MU sizes are one order of magnitude smaller than those in limbs muscles, and also have about 4 times higher firing frequencies, and faster contractile properties (Yu Wai Man et al., 2005). These characteristics allow higher precision and velocity in movements. EOM fibers express all known heavy-chain myosin isotypes (Davis et al., 1986), while limbs muscles express only 4 of them (Briggs \& Schachat, 2002; Schachat \& Briggs, 2002). This in part explains why the contractile properties of both muscle groups are not similar. EOM have also higher mitochondrial content, metabolic rate and a more developed microvascular network, features that make them particularly fatigue resistant (Wooten \& Reis, 1972; Fuchs \& Binder, 1983; Carry et al., 1986). EOM fibers do not fit in the classical 4-type classification of skeletal muscle fibers. They are actually divided in 6 types of EOM fibers, regarding its location (orbital/global), color (white, intermediate or red) and innervation patterns (single or multiple). The multiple innervated fibers, also known as tonictype fibers, are exclusively present in EOM. These fibers are smaller, located more superficially in the muscle, contract slower, and they are involved in slow pursuit movements.

\footnotetext{
${ }^{1}$ Departamento de Oftalmología, Facultad de Medicina, Pontificia Universidad Católica de Chile, Chile.

${ }^{2}$ Departamento de Ciencias Morfológicas, Escuela de Medicina, Universidad Autónoma de Barcelona, España.

${ }^{3}$ Estudiante de Doctorado, Departamento de Ciencias Morfológicas, Escuela de Medicina, Universidad Autónoma de Barcelona, España.
} 
The single innervated fibers, or twitch-type fibers, are seen in all types of skeletal muscle. They are bigger, located deeper in the muscle and involved in rapid-saccadic movements. EOM have even a distinct immune response, having less capacity to control complement reaction (Yu Wai Man et al.; Spencer \& Porter). All these differences make EOM prone to certain diseases, being selectively spared in Duchenne muscular dystrophy and targeted in thyroid eye disease or ocular myasthenia gravis.

The EOM are particularly relevant in strabismus, being the main therapeutic target in procedures that modify their function (i.e. botulinum toxin injection) and anatomy (i.e. strabismus surgery) in order to correct ocular misalignment (Davis et al.; McNeer et al., 2000). EOM histology also undergoes changes in strabismic individuals. Semiquantitative studies have described certain changes in EOM samples of humans with horizontal or vertical strabismus, showing an increased amount of elastin and collagen, and an augmented expression of connective tissue related genes compared to EOM of non-strabismic human controls (Stager Jr. et al., 2013; Agarwal et al., 2016). Nevertheless, histopathology of EOM in strabismus is far to be fully understood (Schiavi, 2016). In fact, there are no histological studies published that quantitatively describe muscle volume, and connective and vascular tissue of EOM, in both healthy and strabismic humans.

The stereological method quantitatively analyses biological tissue samples, giving as result numerical parameters that are unbiased, accurate and reproducible, allowing an easier comparison between different groups (Mandarim-de-Lacerda \& del Sol, 2017).

The aim of this study is to estimate muscular and connective tissue volumes of EOM in humans with no ophthalmological disease using stereology.

\section{MATERIAL AND METHOD}

The specimens studied were five cadaveric human orbits from five male adults without known ophthalmic disease. The samples were donated to the Pontificia Universidad Católica de Chile, and the study was conducted with prior approval of the ethic committee of our institution (project number 12-074).

The orbits were dissected within the first 24 hours postmortem and were preserved in cold between $0-4^{\circ}$ Celsius. The orbital content was removed in toto within the periorbita, through the superior and medial orbital walls. Four rectus muscles and two oblique muscles were isolated from each orbit. The muscles were fixated in a tamponade solution of formaldehyde $10 \%(\mathrm{pH}=7.4)$ for 10 days and then embedded in paraffin. Following the stereological procedure described by Mandarim-de-Lacerda $\&$ delSol (Mandarim-de-Lacerda $\&$ del Sol, 2017) multiple sections of 5- $\mu \mathrm{m}$ thickness were taken. The sections were stained, obtaining five hematoxylineosin, five periodic acid-Schiff (PAS) and five Van Gieson stained sections from each EOM. Five different random fields were evaluated from each stained section. So finally, for each muscle group (for example medial rectus muscles), we analyzed 125 hematoxylin-eosin fields (estimate number of muscle fibers), 125 PAS fields (estimate volume density of vessels) and 125 Van Gieson (estimate volume density of muscle and connective tissue).

For the stereological analysis, every field was digitized using a Nikon ${ }^{\circledR}$ microscope, model Eclise 80 -i, with 4x, 20x and 40x magnification. Volume Density ( $\mathrm{Vv}$ ) is defined as the volume of a component (in this case muscle, vessels or connective tissue) per unit volume of the containing reference space (the field analyzed) and is expressed as a percentage. In relation to data analysis, pairwise comparisons of $\mathrm{Vv}$ Muscle, Vv Collagen and number of fibers per 5,000 $\mu \mathrm{m}^{2}$ between antagonist EOM were conducted using Wilcoxon signed rank test for paired samples. A secondary analysis examining differences between pairs of EOM (vertical, horizontal and oblique) was also conducted. Significance values were based on two-tailed tests, and p-values $<0.05$ were considered statistically significant. No correction by multiple comparisons was performed in this study.

\section{RESULTS}

The mean and standard deviation (SD) of muscle $\mathrm{Vv}$, collagen $\mathrm{Vv}_{\mathrm{v}}$ and number of fibers per $5,000 \mu \mathrm{m}^{2}$ by extraocular muscle are detailed in Table I.

Regarding the $\mathrm{Vv}$ of muscle, pairwise comparisons showed no statistically significant difference between EOM groups (p-value > 0.05). However, the $\mathrm{Vv}$ of muscle of the medial and lateral rectus tended to be higher when compared with the rest of the EOM (Fig. 1). This was more evident when comparing each horizontal muscle, with the superior and inferior rectus, and the superior oblique (p-value 0.06 each pairwise comparison).

In terms of $\mathrm{Vv}$ of collagen, the lateral rectus had the lowest mean of 26.6 followed by the medial rectus with a mean of 28.4 (Table I). The vertical (superior and inferior) rectus and superior oblique muscles showed a similar mean 
Table I. Summary of characteristics by extraocular muscle.

\begin{tabular}{lcccc}
\hline Muscle & $\begin{array}{c}\text { Number of } \\
\text { samples }\end{array}$ & $\begin{array}{c}\text { Mean } \pm \text { SD } \\
\text { Volume density of } \\
\text { muscle }\end{array}$ & $\begin{array}{c}\text { Volume density } \\
\text { of collagen }\end{array}$ & $\begin{array}{c}\text { Number of fibers in } \\
5,000 \text { um }^{2}\end{array}$ \\
\hline Superior rectus & 5 & $54.9 \pm 2.7$ & $32.3 \pm 3.1$ & $17.4 \pm 1.3$ \\
Inferior rectus & 5 & $55.0 \pm 1.9$ & $32.4 \pm 3.0$ & $16.8 \pm 0.9$ \\
Medial rectus & 5 & $62.4 \pm 4.7$ & $28.4 \pm 3.0$ & $18.4 \pm 3.5$ \\
Lateral rectus & 5 & $61.4 \pm 4.8$ & $26.6 \pm 3.8$ & $18.8 \pm 2.0$ \\
Superior oblique & 5 & $51.5 \pm 3.4$ & $32.6 \pm 2.4$ & $18.2 \pm 0.8$ \\
Inferior oblique & 5 & $57.3 \pm 1.9$ & $30.8 \pm 3.4$ & $19.4 \pm 2.2$ \\
\hline
\end{tabular}

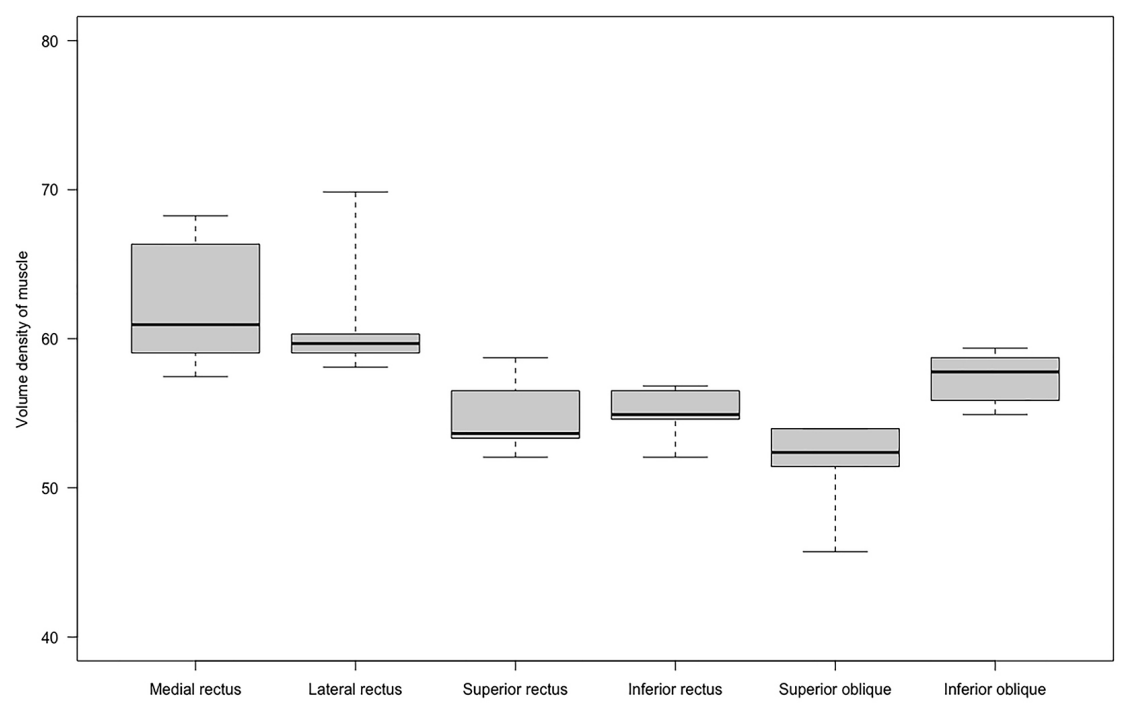

Fig. 1. Boxplot of volume density of muscle by extraocular muscle. The medial and lateral rectus tended to have higher volume density of muscle. There was no statistically significant difference between extraocular muscles ( $\mathrm{p}$-value $>0.05$ ).

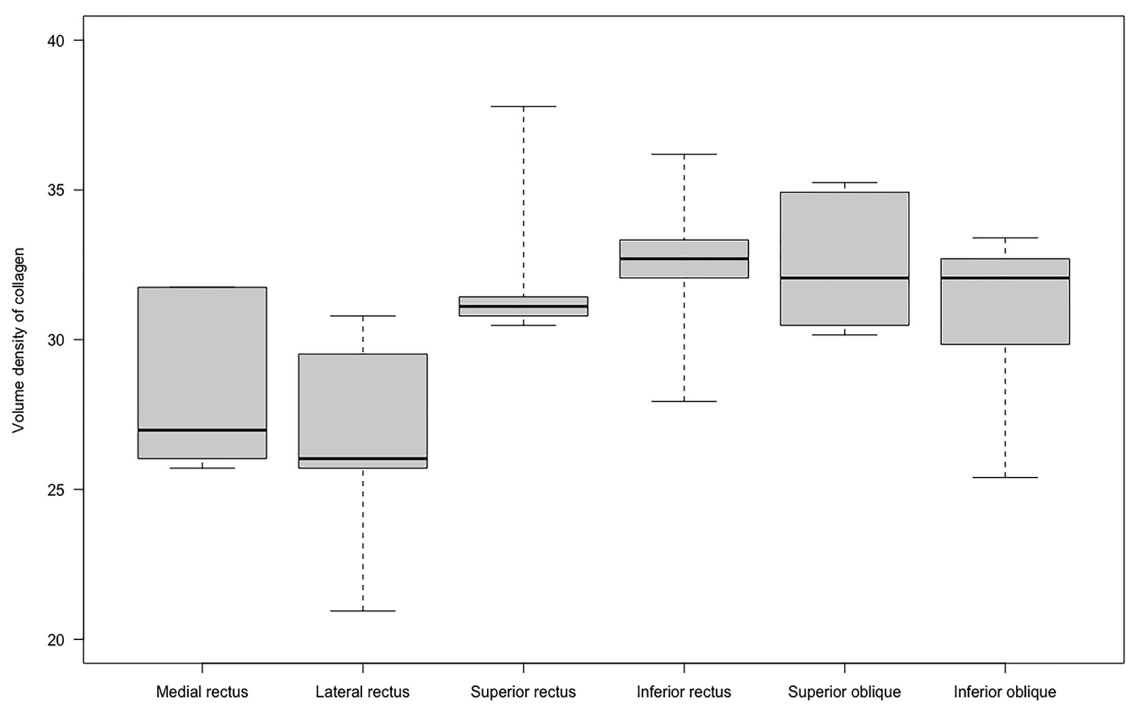

Fig. 2. Boxplot of volume density of collagen by extraocular muscle. The medial and lateral rectus tended to have lower volume density of collagen. There was no statistically significant difference between extraocular muscles ( $\mathrm{p}$-value $>0.05$ ). of Vv of collagen, higher than the horizontal rectus. However, when comparing each horizontal rectus with the superior rectus (p-value 0.1$)$, the inferior rectus (p-value 0.06), and the superior oblique ( $p$-value 0.06 ) muscles, this difference was not statistically significant. The $\mathrm{Vv}$ of collagen by extraocular muscle is shown in Figure 2.

Concerning the number of muscle fibers per $5,000 \mu \mathrm{m}^{2}$, greater dispersion was seen in the horizontal rectus and inferior oblique muscles compared to the vertical rectus and superior oblique (Fig. 3). No statistical differences in pairwise comparison (pvalue $>0.05$ ) were found. However, the inferior rectus tended to have a fewer number of fibers than the rest of the EOM. The number of fibers per $5,000 \mu \mathrm{m}^{2}$ by extraocular muscle is shown in Figure 3.

Examples of Van Gieson (collagen and muscle volume densities) and Hematoxylin-Eosin (number of fibers per $5,000 \mu \mathrm{m}^{2}$ ) stains, for each muscle group, are shown in Figures 4 and 5. 


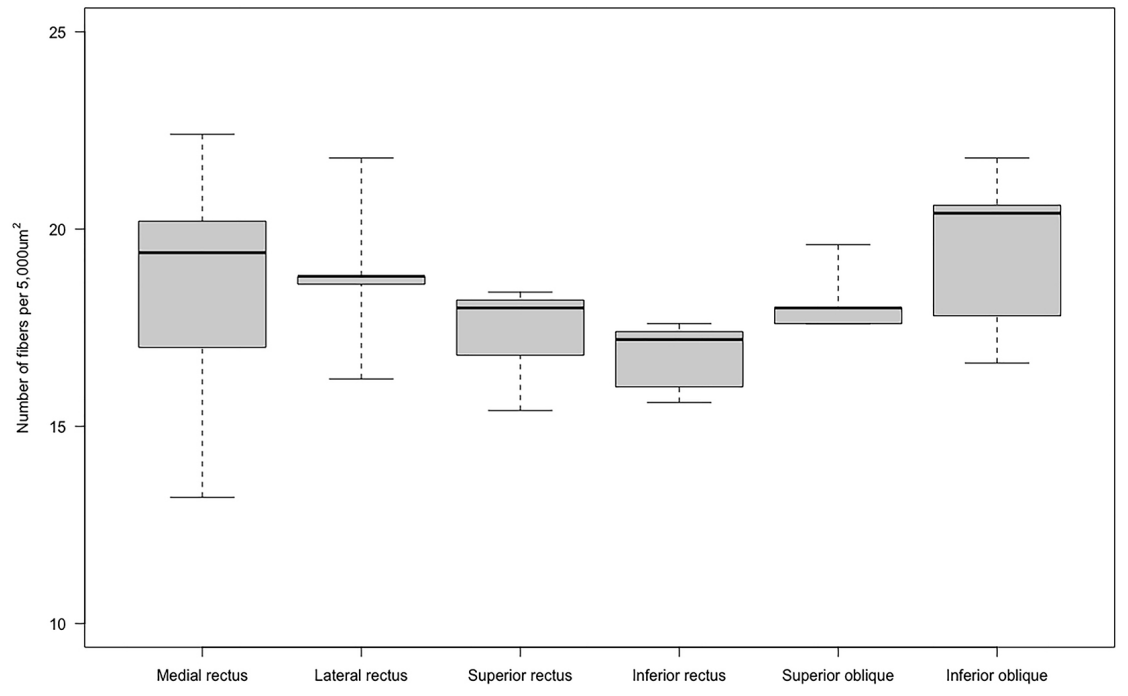

Fig. 3. Boxplot of number of muscular fibers per $5,000 \mu \mathrm{m}^{2}$ by extraocular muscle. The horizontal rectus and inferior oblique had greater dispersion compared to the vertical rectus and superior oblique. There was no statistically significant difference between extraocular muscles ( $\mathrm{p}$-value $>0.05)$.
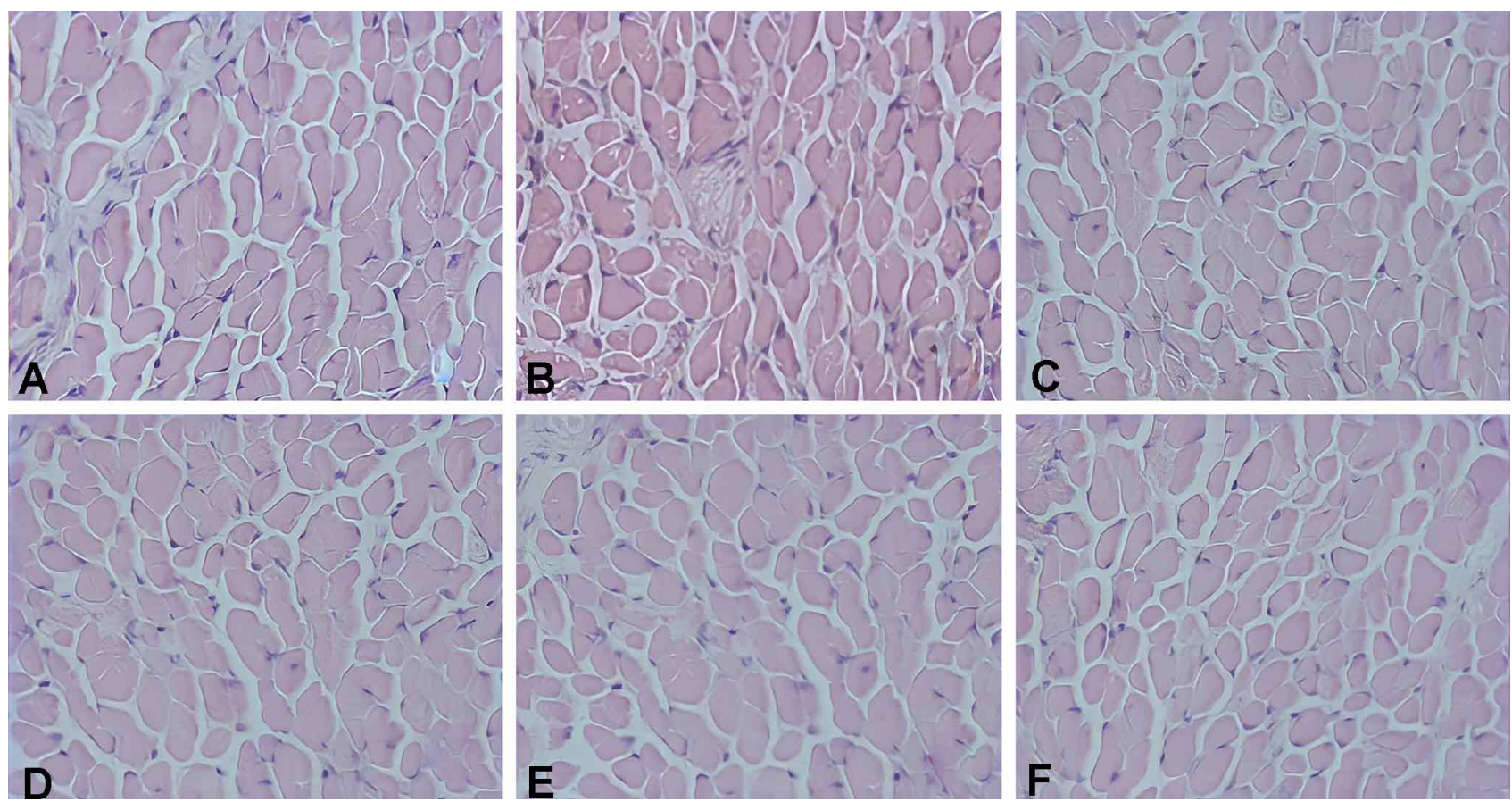

Fig. 4. Optical microscopy, Hematoxylin-Eosin (40X): Each plaque corresponding to a different extraocular muscle: inferior oblique (a), superior oblique (b), inferior rectus (c), lateral rectus (d), medial rectus (e) and superior rectus (f).

\section{DISCUSSION}

The stereological method allows the study of threedimensional biological structures by analyzing two-dimensional histological sections, giving as result reliable numeric parameters. This technique is being used more in a wide range of biomedical fields and is considered the gold standard in quantitative morphometry (Howard \& Reed, 2005; Mühlfeld et al., 2010; Mühlfeld \& Ochs, 2013; Mandarim-de-Lacerda $\&$ del Sol, 2017). The present study describes the normal histology of the extraocular muscles using stereology and specifically determines the proportion of muscle and collagen tissue and quantifies the number of muscle fibers in 5,000 $\mu \mathrm{m}^{2}$. To our best knowledge, there are no previously published 

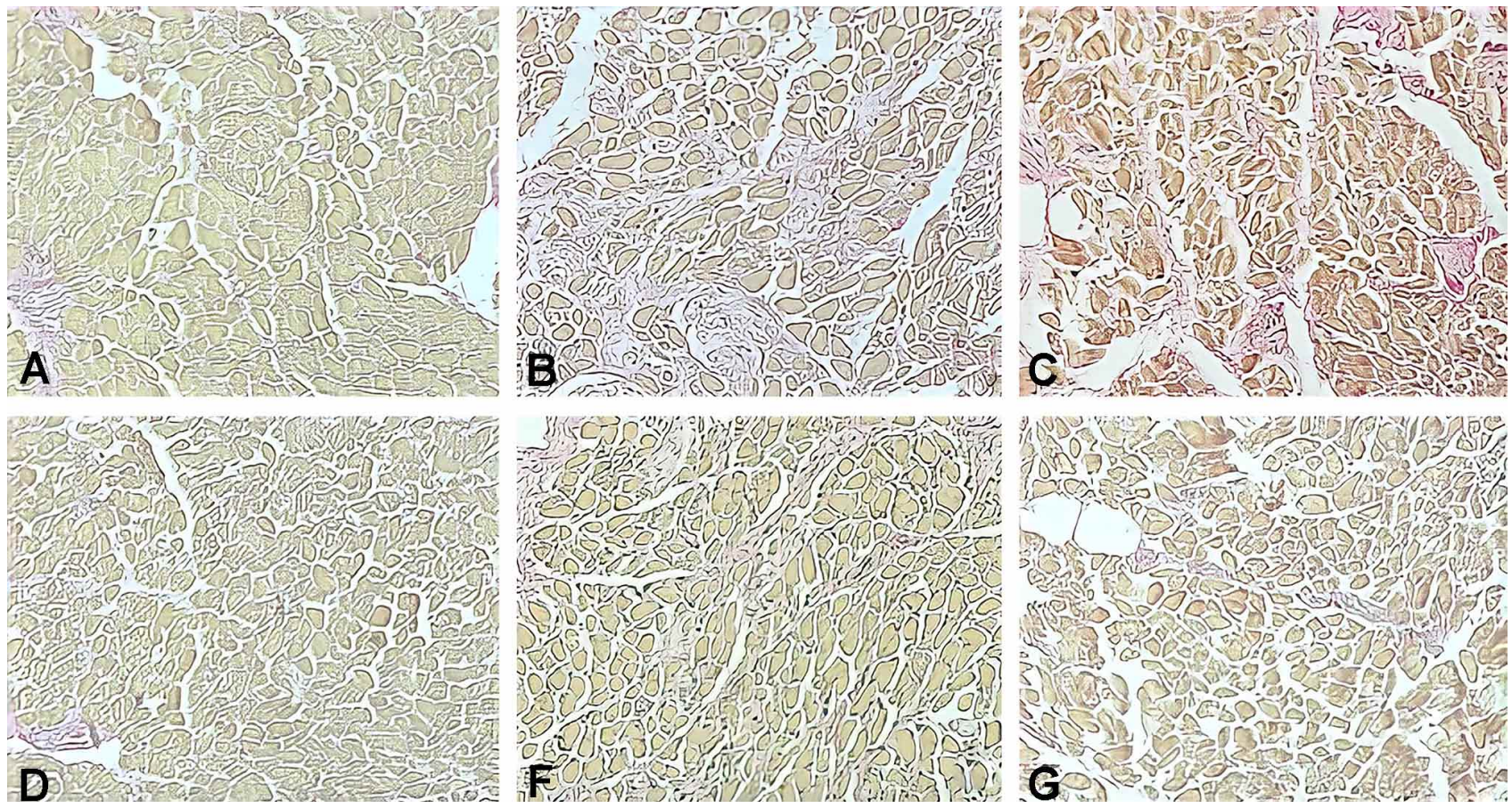

Fig. 5. Optical microscopy, Van Gieson (40X): Each plaque corresponding to a different extraocular muscle: inferior oblique (a), superior oblique (b), inferior rectus (c), lateral rectus (d), medial rectus (e) and superior rectus (f).

studies in which these variables are described in humans, using stereology.

Regarding our results, it is interesting to mention how the histological parameters we studied have a morphological - functional correlation. The horizontal rectus (medial and lateral) showed higher proportion of muscular volume density $(\mathrm{Vv})$ when compared to cyclovertical muscles (vertical rectus and oblique muscles). This is somewhat predictable because lateral versions are the most frequently executed eye movements. The medial rectus showed the highest muscle $\mathrm{Vv}$, a result that is also expected because it is involved in both convergence and lateral movements. Nonetheless, those differences did not achieve statistical significance. Certain level of similarity is expected between the extraocular muscles considering that the oculomotor system is highly balanced, in which yoke (synergistic) and antagonist muscles have been clinically described (Hering et al., 1977; Davis et al.; Bruenech \& Haugen, 2015).

Unfortunately, there are no published stereological studies regarding extraocular muscles histology, in both animals and humans. Several studies have employed stereology for the description of limbs muscle fibers in humans, but they all analyze ultrastructural features, such as mitochondrial volume density (Broskey et al., 2013; Picard et al., 2013). Thus, there is no available data for our results to be compared.
The present study has certain limitations among which are the limited number of individuals analyzed, representing only a specific age range and ethnicity. Additionally, we only described three histological parameters and we do not distinguish between muscle fiber types and collagen subtypes.

\section{CONCLUSION}

This study establishes normal stereological parameters in extraocular muscles of humans without ophthalmological disease. This data will allow future comparisons if similar studies are performed. It would be particularly interesting to see if there is any difference in these stereological parameters in the extraocular muscles of strabismic humans.

SAN MARTÍN, J.; LUNA, C.; GARRETÓN, R.; ARANEDA, S.; SAlgado, C.; RODRÍGUez, A. \& SAlgado, G. Cuantificación estereológica de músculos extraoculares en humanos. Int. J. Morphol., 39(2):506-511, 2021.

RESUMEN: El objetivo de este estudio es cuantificar el volumen de tejido muscular y conectivo de los músculos extraoculares en humanos sin enfermedad oftalmológica conocida utilizando estereología. Los músculos extraoculares fueron obtenidos de cinco cadáveres humanos sin estrabismo. El número de fibras musculares en $5.000 \mu \mathrm{m} 2$ y la densidad de volumen $(\mathrm{Vv}) \mathrm{de}$ 
músculo y colágeno fueron medidas usando estereología. Las comparaciones entre músculos extraoculares antagonistas se realizaron a través de la prueba de los rangos con signo de Wilcoxon para muestras pareadas. Un análisis secundario examinando diferencias entre pares de músculos extraoculares también fue llevado a cabo. Se realizaron pruebas bilaterales y la significancia fue fijada en 0,05 . Los músculos rectos horizontales (recto medial y lateral) tuvieron el mayor $\mathrm{Vv}$ de músculo y el menor Vv de colágeno. El músculo recto inferior tuvo la tendencia a poseer menos número de fibras por $5.000 \mu \mathrm{m}^{2}$ que el resto de los músculos extraoculares. No obstante, estas diferencias no llegaron a ser estadísticamente significativas. Este es el primer estudio publicado describiendo la histología normal de los músculos extraoculares usando estereología. Nuestra investigación, a través de la cuantificación de la proporción de tejido de músculo y colágeno, así como el número de fibras musculares en $5.000 \mu \mathrm{m}^{2}$, establece parámetros estereológicos normales para músculos extraoculares en humanos sin enfermedad oftalmológica.

PALABRAS CLAVE: Músculos oculomotores; Humanos; Histología; Anatomía.

\section{REFERENCES}

Agarwal, A. B.; Feng, C. Y.; Altick, A. L.; Quilici, D. R.; Wen, D.; Alan, L. A. \& von Bartheld, C. S. Altered protein composition and gene expression in strabismic human extraocular muscles and tendons. Investig. Ophthalmol. Vis. Sci., 57(13):5576-85, 2016.

Briggs, M. M. \& Schachat, F. The superfast extraocular myosin (MYH13) is localized to the innervation zone in both the global and orbital layers of rabbit extraocular muscle. J. Exp. Biol., 205(Pt. 20):3133-42, 2002.

Broskey, N. T.; Daraspe, J.; Humbel, B. M. \& Amati, F. Skeletal muscle mitochondrial and lipid droplet content assessed with standardized grid sizes for stereology. J. Appl. Physiol. (1985), 115(5):765-70, 2013.

Bruenech, J. R. \& Haugen, I. B. K. How does the structure of extraocular muscles and their nerves affect their function? Eye (Lond.), 29(2):17783, 2015.

Büttner-Ennever, J. A. Anatomy of the oculomotor system. Dev. Ophthalmol., 40:1-14, 2007.

Carry, M. R.; Ringel, S. P. \& Starcevich, J. M. Mitochondrial morphometrics of histochemically identified human extraocular muscle fibers. Anat. Rec., 214(1):8-16, 1986.

Davis, G.; McNeer, K. W. \& Spencer, R. F. Myectomy of the inferior oblique muscle. Arch. Ophthalmol., 104(6):855-8, 1986.

Fuchs, A. F. \& Binder, M. D. Fatigue resistance of human extraocular muscles. J. Neurophysiol., 49(1):28-34, 1983.

Hering, E.; Bridgeman, B. \& Stark, L. The Theory of Binocular Vision. New York, Plenumm Press, 1977.

Hoh, J. F. Y.; Hughes, S.; Hugh, G. \& Pozgaj, I. Three Hierarchies in Skeletal Muscle Fiber Classification: Allotype, Isotype and Phenotype. In Kedes, L. H. \& Stockdale, F. E. (Eds.). Cellular and Molecular Biology of Muscle Development. New York, Alan R. Liss, 1989.

Howard, C. V. \& Reed, M. G. Unbiased Stereology: Three-Dimensional Measurement in Microscopy. 2nd ed. New York, BIOS Scientific Publishers, 2005.

Mandarim-de-Lacerda, C. A. \& del Sol, M. Tips for studies with quantitative morphology (morphometry and stereology). Int. J. Morphol., 35(4):148294, 2017.

McNeer, K. W.; Tucker, M. G. \& Spencer, R. F. Management of essential infantile esotropia with botulinum toxin A: review and recommendations. J. Pediatr. Ophthalmol. Strabismus, 37(2):63-7, 2000.
Mühlfeld, C. \& Ochs, M. Quantitative microscopy of the lung: a problembased approach. Part 2: stereological parameters and study designs in various diseases of the respiratory tract. Am. J. Physiol. Lung Cell. Mol. Physiol., 305(3):L205-21, 2013.

Mühlfeld, C.; Nyengaard, J. R. \& Mayhew, T. M. A review of state-of-theart stereology for better quantitative 3D morphology in cardiac research. Cardiovasc. Pathol., 19(2):65-82, 2010.

Picard, M.; White, K. \& Turnbull, D. M. Mitochondrial morphology, topology, and membrane interactions in skeletal muscle: a quantitative three-dimensional electron microscopy study. J. Appl. Physiol. (1985), 114(2):161-71, 2013.

Porter, J. D.; Baker, R. S.; Ragusa, R. J. \& Brueckner, J. K. Extraocular muscles: basic and clinical aspects of structure and function. Surv. Ophthalmol., 39(6):451-84, 1995.

Schachat, F. \& Briggs, M. M. Phylogenetic implications of the superfast myosin in extraocular muscles. J. Exp. Biol., 205(Pt. 15):2189-201, 2002.

Schiavi, C. Extraocular muscles tension, tonus, and proprioception in infantile strabismus: role of the oculomotor system in the pathogenesis of infantile strabismus-Review of the literature. Scientifica (Cairo), 2016:5790981, 2016.

Spencer, R. F. \& Porter, J. D. Biological organization of the extraocular muscles. Prog. Brain Res., 151:43-80, 2006.

Stager Jr., D.; McLoon, L. K. \& Felius, J. Postulating a role for connective tissue elements in inferior oblique muscle overaction (an American Ophthalmological Society thesis). Trans. Am. Ophthalmol. Soc., 111:11932, 2013.

Wooten, G. F. \& Reis, D. J. Blood flow in extraocular muscle of cat. Arch. Neurol., 26(4):350-2, 1972.

Yu Wai Man, C. Y.; Chinnery, P. F. \& Griffiths, P. G. Extraocular muscles have fundamentally distinct properties that make them selectively vulnerable to certain disorders. Neuromuscul. Disord., 15(1):17-23, 2005.

\section{Corresponding author:}

Dr. Guillermo Salgado

Estudiante de Doctorado

Departamento de Ciencias Morfológicas

Escuela de Medicina

Universidad Autónoma de Barcelona

Los Militares 4777

Torre 1, Piso 8

Las Condes, Santiago

CHILE

\section{E-mail: gsalgadoalarcon@gmail.com}

Received: 18-12-2020

Accepted: 13-01-2021 